\title{
Issues regarding the impact of the coronavirus pandemic on the labour market
}

\author{
Alina Nițescu $^{1 *}$ \\ ${ }^{1}$ University of Petroșani, Department of Economic Science, University Street, no.20, Petrosani, \\ Romania
}

\begin{abstract}
A year has passed since humanity was hit, on all levels, by the COVID-19 pandemic. In addition to the specific health, social, moral, etc. consequences, the pandemic has strongly influenced, perhaps in some segments even irretrievably, the economic sector, causing a new economic crisis that has put pressure on the economies of all states in the world. In this context, the labor market as a whole has recently undergone important changes, which have led to its transformation and the emergence or deepening of vulnerabilities. Thus, the paper aims to capture the main consequences of the pandemic on the labor market, especially on the fragile balance of the labor market in Romania.
\end{abstract}

\section{Introduction}

The labor market is a special market because its object is labor. Characterized by an extremely dynamic and complex content, the labor market can be highlighted, distinctly, both by its components and types, as well as by the influencing factors and segments of which it is constituted.

Due to the particularities that derive from the specificity of the "object" of the transactions, the labor market receives the influences of the other markets and, at the same time, generates effects that are found in all sectors of the economy.

The labor market reflects the reciprocal links between the demographic realities that determine labor supply and those of economic and social development that generate labor demand. At the same time, the level of economic and social development, together with other factors such as socio-political and natural events, the dynamics of the emigrationimmigration process, technological progress, labor productivity, etc., can decisively influence this fragile balance between demand and supply of labour force.

In the current period, the main factor influencing the labor market, with all the aspects that have occurred here, has been the coronavirus pandemic, which has caused multiple changes in almost all sectors of activity.

In fact, the issue of employment, the analysis of developments in labor markets facing major challenges following the coronavirus pandemic, as well as how to maintain the functioning of the labor market and the nature of inclusion are the subject of much research.

\footnotetext{
* Corresponding author: al.nitescu@gmail.com
} 


\section{Effects and measures}

Practically, the Covid 19 pandemic caused an economic crisis, which affected the economies of the states and implicitly reverberated on the labor market, the effects being felt both in terms of unemployment, inactivity and in view of the changes that have occurred on the typical and structure of work.

A worldwide study by the International Labor Organization outlined a series of consequences of the coronavirus pandemic on labor markets. Thus, the number of hours worked in 2020 was estimated to decrease by $8.8 \%$ compared to the fourth quarter of 2019 , and losses in working hours in 2020 were approximately four times higher than during the global financial crisis of 2009. Globally, the decline in the work schedule in 2020 has resulted in both job losses and a reduction in the work schedule for those who have remained busy, with significant variations between regions. At the same time, reference is made to the reduction of incomes by $8.3 \%$ in 2020 compared to the previous year. [1]

At the level of the European Union countries too, the job losses have translated both in the increase of the inactivity rate, but also in the increase of the unemployment rate. Both at the level of the European Union and at the level of our country, the tendency to increase the unemployment rate was obvious. - Fig. 1

The shock caused by the appearance of COVID-19 and the restrictions imposed by all European Union countries was immediately felt on the labor market, also reflected in the level of unemployment.

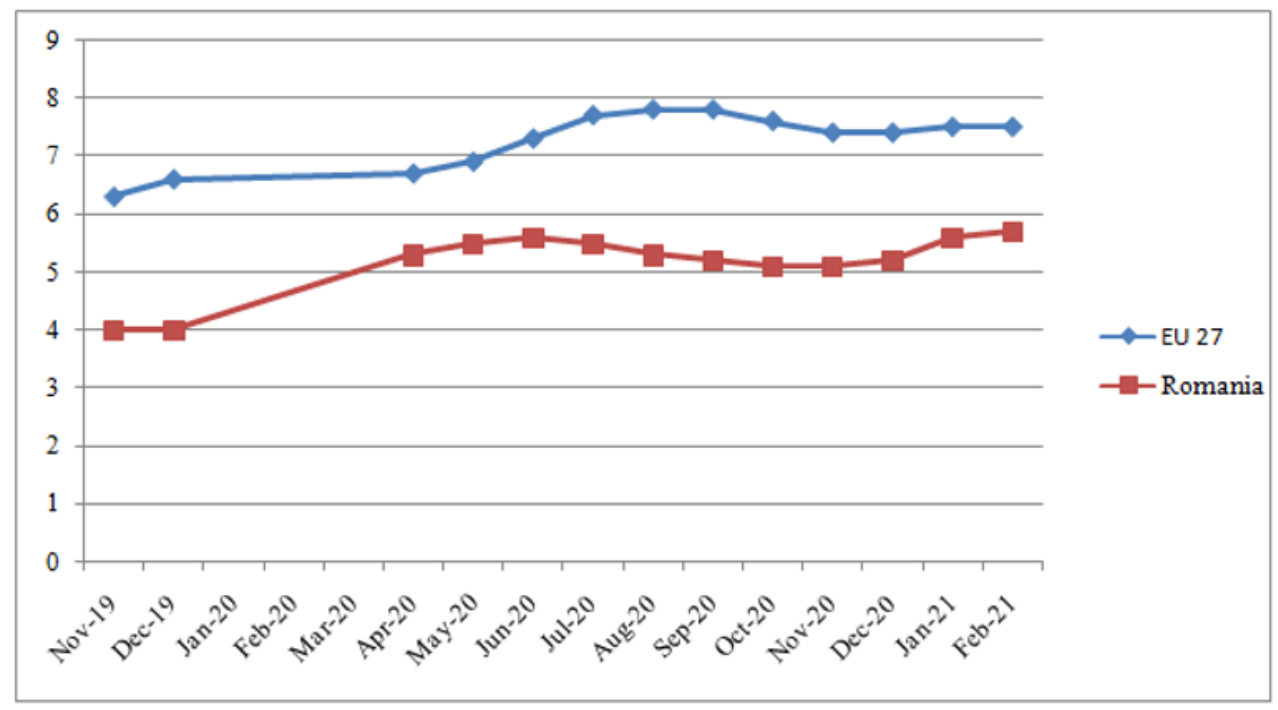

Fig. 1.Unemployment rate (\%)

Sursa: https://ec.europa.eu/eurostat/web/lfs/visualisations

As can be seen from the figure above, with the spread of the coronavirus in Europe at the beginning of 2020, changes took place in the labor market, caused in particular by the closure or restriction of the activity of many companies, which had repercussions on the unemployment rate. It evolved upwards throughout the analyzed period. At the level of our country, the unemployment rate is in the same upward trend with the mention that, in value, it is lower than the European average.

At the level of our country, the main industries affected by the massive job losses were transport, tourism, HoReCa, entertainment, trade, manufacturing, construction. On the 
contrary, there has been a positive increase in employment in a number of service sectors such as information and communication and financial and insurance activities. The economic activities in which work itself could be replaced by telework, as well as those in which there was a rapid digital transformation, suffered the least. This is also observed at the employee level; those employees who had the skills and competencies necessary for a reorientation towards automated, digitized activities were the least exposed to the phenomenon of unemployment.

A number of measures have been applied in our country to reduce the impact of the economic crisis caused by the COVID-19 pandemic on the labor market.

One of the measures aimed at granting the unemployment benefit for workers with suspended employment contracts during the state of emergency, starting with March 16, 2020. The level of the allowance was set at $75 \%$ of the basic salary in the contract, with a maximum of $75 \%$ of the average gross earnings per economy for the current year; the technical unemployment benefit was borne from the unemployment insurance budget. It was a measure that came as a "mouthful of oxygen" for both employees and employers in this context. According to the Ministry of Labor, the possibility of granting the technical unemployment allowance for the areas restricted by the authorities has been extended until June 30, 2021.

At the end of March 2020, the Ministry of Labor and Social Protection announced that about 400,000 employment contracts had been suspended since the start of the state of emergency. At the beginning of the following month, the number of suspended contracts exceeded one million. Subsequently, in May, the number of suspended employment contracts began to decline, but the number of employment contracts terminated since the declaration of a state of emergency increased, to reach almost 420,000 at the end of May. For June, July, the Ministry of Labor did not provide data on the number of terminated employment contracts. - Fig. 2

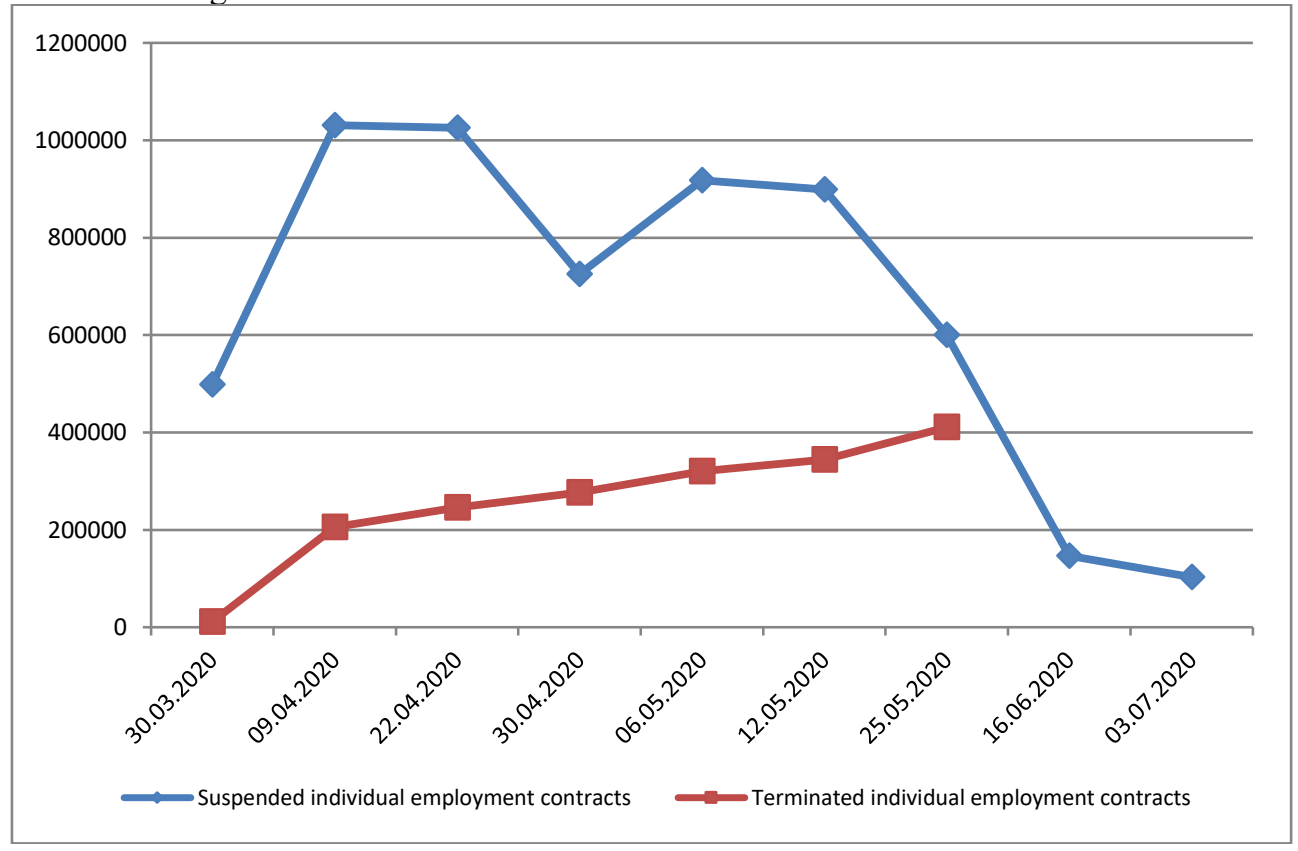

Fig. 2. Evolution of the number of individual employment contracts suspended and terminated

Sursa: www.mmuncii.ro 
From the analysis of the sectors in which the highest number of individual terminated employment contracts was found, it was observed that the most affected are trade and manufacturing, construction, HoReCa, areas that concentrate over $50 \%$ of the total number of terminated contracts.

Another active measure, aimed at reducing unemployment and encouraging the retention of employees, is the $41.5 \%$ subsidy of the salaries of employees whose employers have reactivated their previously suspended employment contracts, during the state of emergency. Thus, the employees who benefited from technical unemployment in the context of the pandemic and whose employment relations were maintained after the resumption of activity by employers, benefited, for a period of three months, through the employer, from the payment of $41.5 \%$ from the basic salary corresponding to the job held, but, not more than $41.5 \%$ of the average gross earnings.

The third measure to support employers and employees, adopted in early August 2020, refers to the German model of "flexible work" or "kurzarbeit". This measure provides for the subsidization of the salaries of employees whose work schedule is reduced as a result of the reduction of the company's activity. This model offers employers whose activity has been affected by the coronavirus pandemic the opportunity to reduce the working time of employees, so that they do not have to resort to redundancies, without affecting their income too much. Specifically, based on this model, the employer reduces the employee's schedule, pays him according to the new working time, and the difference from the initial salary is borne by the state to a certain extent. Currently, this model is applied in European Union countries such as Germany, Austria, Slovenia, France. In the context of the application of this measure, in order to ensure business continuity, employers must pay more attention to the efficient management of human and financial resources, so as to ensure the maintenance and even increase of employee productivity.

This measure can be successfully applied in areas affected by the pandemic, such as the manufacturing industry, where production has declined as a result of declining foreign trade and the temporary closure of certain sectors of activity during the state of emergency and alert.

A particularly current issue currently reported on the labor market is the vulnerability of people with a low level of vocational training, low incomes, as well as those who carry out seasonal gainful activities. To a large extent, these people do not have the necessary skills to reorient themselves in the labor market, nor can they wait too long to find another job, and in some cases they cannot even benefit, from a legal point of view, by the measures intended to reduce unemployment. In this category we can also include workers who ensure their existence by working, seasonally, in other countries, especially in the context in which the free movement between the countries of the European Union has been limited.

In the current context, of the changes that take place in the national economies and implicitly on the labor market, both at national level and at the level of the European Union, it is necessary to take into account the issue of workers without legal forms, who cannot benefit from protection, social services, health services, etc. and which, in some cases, were left completely without income.

Another effect of the coronavirus pandemic on the labor market refers to the deepening of gender inequalities in the labor market, a larger number of women being in the situation of losing or giving up their jobs during the pandemic.

As a corollary of the above, we can appreciate that the labor market in the countries affected by the coronavirus pandemic has never been as disturbed as in 2020 . There was a need for increased flexibility and adaptability of both employers and employees, towards a rapid reorientation, both in terms of the program and the working methods. 
Although the global economy is still facing high levels of uncertainty, economic activities and, implicitly, the labor market are expected to recover, especially in the second half of this year, under the circumstances of progress in vaccination.

\section{Perspectives}

The pandemic and the new reality of the labor market have changed the vision and priorities of both companies and employees.

Given that the digital transformation occupies a very important place nowadays, employees and employers will have to adapt to these changes, their level of flexibility and adaptability playing a key role during this period. For example, a hybrid system of work alternating office work with home work, in the economic sectors where this is possible, can be an effective model, especially in terms of costs, but also labor productivity and employee satisfaction. Thus, the trend is outlined in which performance is evaluated and rewarded, more and more, based on the results, rather than the hours worked.

At the same time, companies, in an effort to continue their activity and retain their employees, are willing to offer employees new categories of benefits such as medical, epidemiological testing and / or vaccination of staff. At the same time, employers are now more interested in employees' soft skills, such as creativity, empathy, emotional intelligence, stress management, than in their hard skills.

\section{References}

1. ILO Monitor: COVID-19 and the world of work. Seventh edition Updated estimates and analysis. Available https://www.ilo.org/wcmsp5/groups/public/@dgreports/@dcomm/documents/briefingnote/wcms 767028.pdf

2. Ocuparea forței de muncă și piețele muncii. Available on https://www.eurofound.europa.eu/ro/topic/employment

3. Lucruri care vor defini piața muncii în 2021. Available on https://www.adecco.ro/5-lucruri-carevor-defini-piata-muncii-in-2021/

4. Ce cred angajatorii despre piața muncii în 2021. Available on https://www.hipo.ro/locuri-demunca/vizualizareArticol/3086/Ce-cred-angajatorii-despre-piata-muncii-din-2021\%3F

5. Impactul COVID-19 pe piața muncii. Available on https://ro.gigroup.com/wpcontent/uploads/sites/12/2020/09/Impactul-Covid-19-pe-piata-muncii.pdf

6. L. Chivu, G.Georgescu, Labor market vulnerabilities under theCOVID-19 impact in Romania. Available on https://mpra.ub.uni-muenchen.de/101676/1/MPRA_paper_101676.pdf

7. A. Niţescu, Annals of the University of Petroşani 19(1), 99-106 (2019) 